\title{
MEASUREMENT OF PRODUCTION PROCESS PRODUCTIVITY OF BOLT HEXAGON NUT M10 X 60MM WITH JUST IN TIME METHODS AND MANUFACTURING CYCLE EFFECTIVENESS (MCE) TO REDUCING NON VALUE ADDED ACTIVITY
}

\author{
Indah Apriliana Sari ${ }^{1}$, Reynaldi Septi $W^{2}$, Darmadi ${ }^{3}$ \\ ${ }^{1,2,3}$ Industrial Engineering - Faculty of Engineering \\ University of 45 Surabaya \\ indahaprilianasari@gmail.com
}

\begin{abstract}
The purpose of this research is to calculate the value of productivity carried out in the production of Bolt Hexagon Nut M10X 60MM that have applied the Just in Time method. Machine productivity calculations are carried out using Manufacturing Cycle Effectiveness (MCE) to reduce non-value-added processes. The results of research conducted from January to December 2017 showed an increase in the MCE value of $35 \%$, and productivity increased by $139.75 \mathrm{~kg} /$ hour for one year. The calculation shows that MCE is very effective for use in planning and improving value-added activities.
\end{abstract}

Keywords : Productivity, Just in Time, Manufacturing Cycle Effectiveness, Bolt Hexagon Nut

\section{INTRODUCTION}

Productivity is a factor that greatly influences the development of an industry. Productivity measurement is used to determine the level of performance that has been achieved as an effort of continuous improvement. Therefore, the company engaged in making Hexagon Nut Bolts measures productivity to determine the effectiveness of ongoing production processes and as a basis for evaluating further productivity improvements. One approach that can be done to improve productivity, improve competitiveness, and the quality and cost of products is to apply the Just in Time (JIT) method (Wilopo \& Purnamasari, 1996 and quoted by Wardhana, 2018).
One of the philosophies of implementing JIT where an activity that does not provide added value to the product or service is waste. A product that is difficult in its manufacturing process, because a bad design and without standardization is also waste. Toyota identifies 7 producers of waste due to poor manufacturing methods, among others (Hong, _ _ ):

1. Waste of overproduction

2. Waste of waiting

3. Waste of movement

4. Waste of inventories

5. Waste of motion

6. Waste of making defects

7. Waste of process itself

The waste producer above automatically lead a high production costs. So, to reduce it the company must evaluate it. According Satiana et al (2007), which was cited by Putri et.al (2016), it is necessary to improve the activities to achieve cost effectiveness to reduce the cost of excessive production. Therefore, the concept of cost effectiveness or manufacturing cycle effectiveness (MCE) can be applied in this research to get continuous improvement.

Just In Time (JIT) is a technique that has been used successfully in Japan for more than 20 years to help manufacturing company to operate more effectively, and make planning and evaluation to be efficient. It can the manufacture process to be faster.

The purpose of implementing JIT is to slowly improve (step by step) and continuous or one less at a time, such as being more responsive to consumers, becoming flexible, to get better quality, and to reduce production cost. 


\section{Tibuana}

Journal of applied Industrial Engineering-University of PGRI Adi Buana

p-ISSN 2622-2027

$e$-ISSN 2622-2035

The procedure of "one less at a time" above follows figure 1. While the effects of reduced storage or "one inventory less" can be expressed as in figure 2, where in the picture shows more effective and efficient activities. To reduce the amount of product storage, it is necessary to increase the level of product quality, the production process with no defects, and better preventive maintenance. In addition, it also requires more intense communication between departments, consumers and suppliers (Hong,

Manufacturing Cycle Effectiveness (MCE) is a method used to analyze production activities, regarding how long a product spends from handling raw materials to finished products. MCE is a percentage value of value added activities, which are used by companies to provide value to consumers. The value of production efficiency is obtained from the comparison of processing time with cycle time and is called Cycle Effectiveness (CE).

If $\mathrm{CE}=100 \%$, means non value added process has been successfully eliminated, so consumers are no burdened with the costs of non value added.

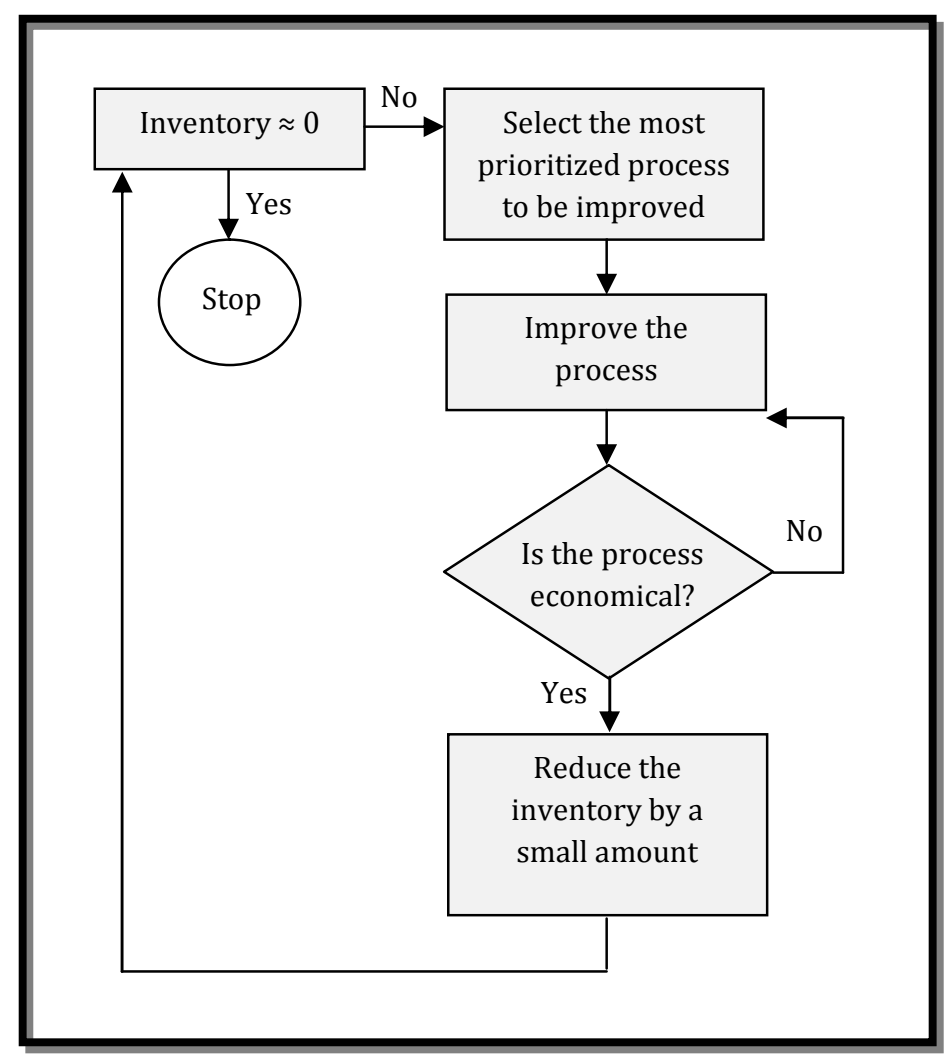

Figure 1. Procedure of "one less at a time" 


\section{Tibuana}

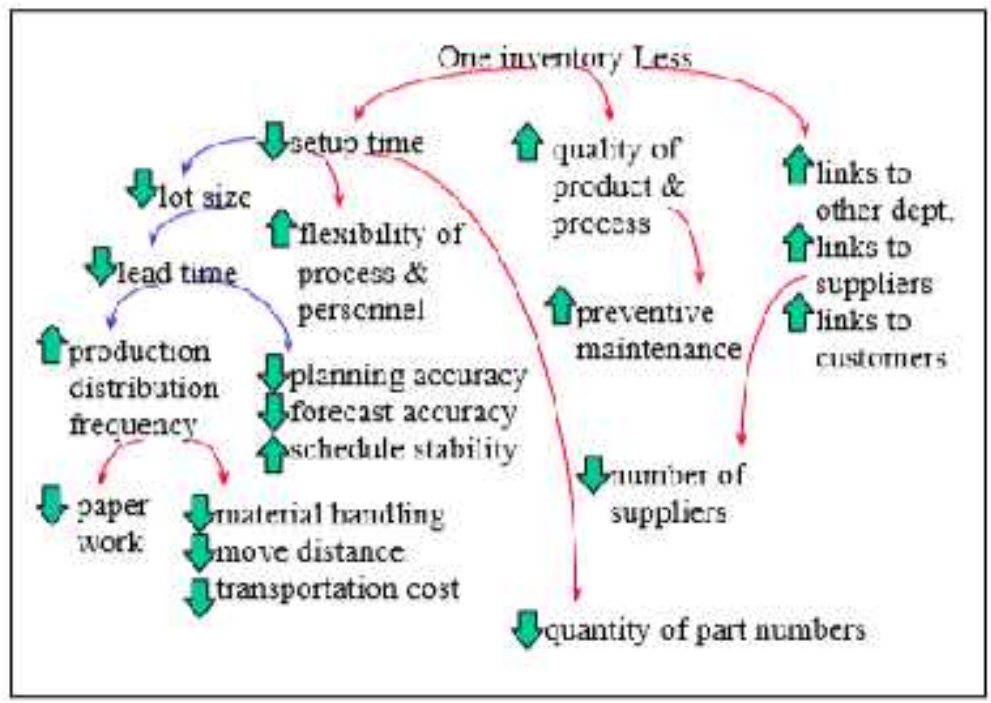

Figure 2. The effects of reduced storage

If $\mathrm{CE}<100 \%$, there is still a non value added for consumers. It is indicates the amount of resources consumed in the process. However, if CE close to $100 \%$, it means that the use of resources to realize activities are value added more effective (Putri et.al, 2016).

The cycle time calculation that will be used to determine the amount of Cycle Effectiveness can be calculated using the following formula (Purnamasari et al, 2018):

\begin{aligned} & Cycle time $=$ Processing time + \\ & Waiting time \\ &+ Moving time + \\ & inspection \\ & time/storage time \\ & \hline\end{aligned}

$$
\text { MCE }=\frac{\text { Processing Time }}{\text { Cycle Time }}
$$

\section{RESEARCH METODOLOGY}

The outline of the implementation of this research is shown in the following flow diagram.

\section{Productivity}

Productivity is a ratio between output and input. The value (index) shows the effectiveness of production that has been done to increase output and the amount of efficiency of the source / raw material / input that can be saved.

Productivity is often associated with the terms effectiveness and efficiency. The term effectiveness relates to achievement, while efficiency leads to the large use of resources / raw materials / inputs used in achieving goals (Singgih, 2012).

$$
\text { Productivity }=\frac{\text { Output }}{\text { Input }}
$$




\section{Tibuana}

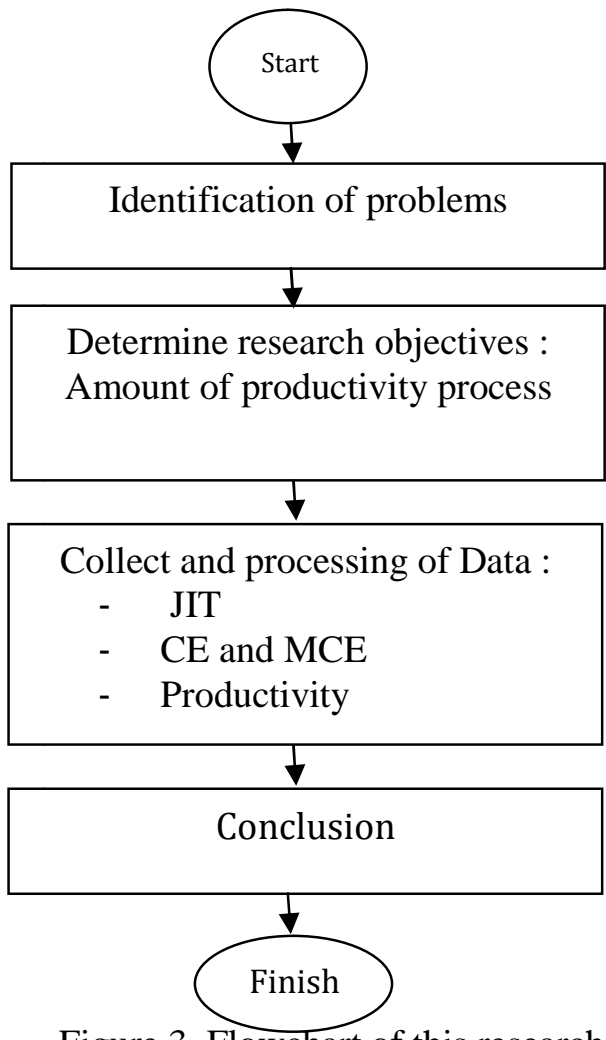

Figure 3. Flowchart of this research

\section{RESULT AND DISCUSSION}

In this sub-chapter, it will be shown about the operation process of making M10 $\mathrm{X} 60 \mathrm{MM}$ Hexagon Nut bolts to make it easier to identify value-added and non-valueadded activities. Figure 4 below is a picture of the operation of the Hexagon Nut M10X $60 \mathrm{MM}$ Bolt, which shows the number of operations as many as 6 times, 2 times inspection, and 1 time storage.

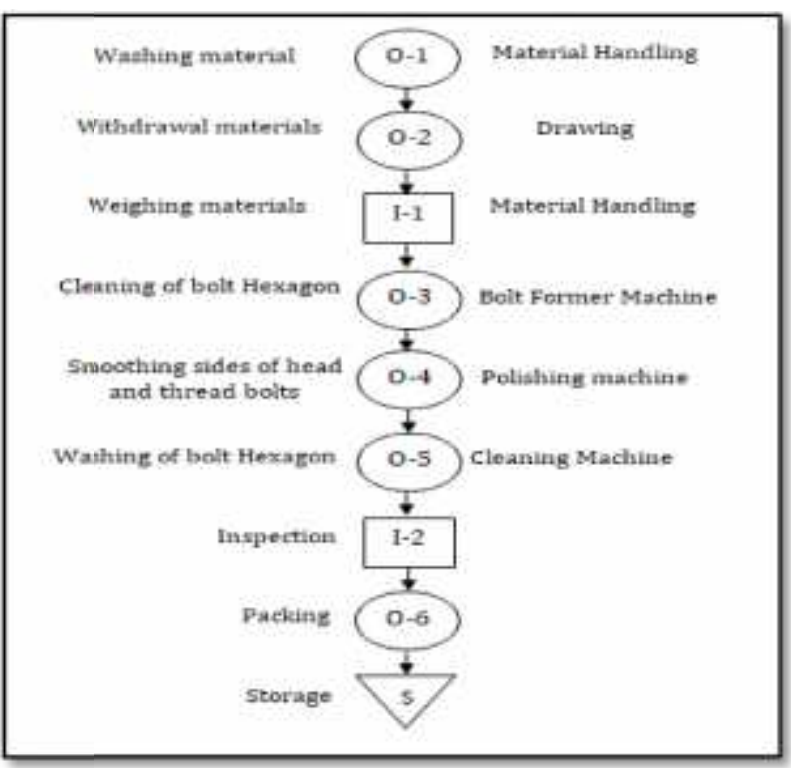

Figure 4. Diagram Operation Process of bolt Hexagon Nut 
Table 2. Data on the production of Hexagon Nut M10 X 60 MM Bolt in 2016

\begin{tabular}{cc} 
Month & Total $(\mathrm{Kg})$ \\
\hline January & 15.730 \\
February & 48.000 \\
Mach & 53.400 \\
April & 28.800 \\
Mai & 10.800 \\
June & 12.000 \\
July & 12.000 \\
August & 16.500 \\
September & 30.000 \\
October & 35.000 \\
November & 15.000 \\
December & 30.000 \\
Total & 307.230 \\
\hline
\end{tabular}

Table 3. Data activity of Processing Time of Hexagon Nut Bolt in 2016 (existing)

\begin{tabular}{|c|c|c|c|c|c|c|c|c|c|c|c|c|c|c|c|}
\hline \multirow{2}{*}{ No } & \multirow{2}{*}{$\begin{array}{l}\text { Production } \\
\text { activity }\end{array}$} & \multirow[b]{2}{*}{ Jan } & \multirow[b]{2}{*}{ Feb } & \multirow[b]{2}{*}{ Mar } & \multicolumn{5}{|c|}{ Processing time (hour)/month } & \multirow[b]{2}{*}{ Sep } & \multirow[b]{2}{*}{ Ok } & \multirow[b]{2}{*}{ Nov } & \multirow[b]{2}{*}{ Dec } & \multirow{2}{*}{ Total } & \multirow{2}{*}{$\begin{array}{l}\text { Aver- } \\
\text { age }\end{array}$} \\
\hline & & & & & Apr & Mei & Jun & Jul & Aug & & & & & & \\
\hline \multirow[t]{2}{*}{1} & Transfer of & & & & & & & & & & & & & & \\
\hline & $\begin{array}{l}\text { BB from } \\
\text { warehouse to } \\
\text { production } \\
\text { floor }\end{array}$ & 26 & 26,52 & 26,26 & 26 & 26,52 & 26 & 27,04 & 26 & 27,3 & 26,78 & 26,52 & 26,26 & 317,2 & 26,43 \\
\hline 2 & $\begin{array}{l}\text { Washing of } \\
\text { raw materials }\end{array}$ & 9,1 & 9,1 & 13 & 10,4 & 9,1 & 13 & 9,1 & 7,8 & 9,1 & 9,26 & 12,48 & 10,4 & 121,84 & 10,15 \\
\hline 3 & $\begin{array}{l}\text { Withdrawal of } \\
\text { raw materials }\end{array}$ & 10,4 & 7,8 & 13 & 10,4 & 13 & 7,8 & 13 & 10,4 & 10,4 & 13 & 7,8 & 9,1 & 126,1 & 10,51 \\
\hline 4 & $\begin{array}{l}\text { Weighing raw } \\
\text { materials }\end{array}$ & 26 & 26,26 & 27,04 & 26,26 & 26,26 & 26 & 26,26 & 26 & 26 & 27,3 & 26 & 27,04 & 316,42 & 26,37 \\
\hline 5 & $\begin{array}{l}\text { Hexagon bolt } \\
\text { formation }\end{array}$ & 13 & 8,32 & 9,1 & 8,84 & 7,8 & 13 & 13 & 13 & 13 & 14,3 & 14,3 & 14,3 & 141,96 & 11,83 \\
\hline 6 & $\begin{array}{l}\text { Smoothing } \\
\text { the sides of } \\
\text { the head and } \\
\text { thread bolts }\end{array}$ & 9,1 & 13 & 7,8 & 13 & 13,52 & 13 & 10,4 & 13 & 10,4 & 10,4 & 14,4 & 9,1 & 137,12 & 11,43 \\
\hline 7 & $\begin{array}{l}\text { Washing } \\
\text { hexagon bolts }\end{array}$ & 10,4 & 13 & 13 & 13 & 8,32 & 10,4 & 10,4 & 10,4 & 13 & 7,8 & 10,4 & 9,1 & 129,22 & 10,77 \\
\hline 8 & $\begin{array}{l}\text { Inspection by } \\
\text { QC }\end{array}$ & 13 & 13 & 7,8 & 11,7 & 12,48 & 10,4 & 13 & 13 & 13 & 10,4 & 9,1 & 10,4 & 137,28 & 11,44 \\
\hline 9 & $\begin{array}{l}\text { Packing and } \\
\text { storage }\end{array}$ & 13 & 13 & 13 & 10,4 & 13 & 10,4 & 10,4 & 10,4 & 7,8 & 10,4 & 9,1 & 14,3 & 135,2 & 11,27 \\
\hline \multicolumn{2}{|c|}{$\begin{array}{l}\text { Total processing } \\
\text { time }\end{array}$} & 130 & 130 & 130 & 130 & 130 & 130 & 132,6 & 130 & 130 & 129,64 & 130,1 & 130 & & \\
\hline & & & & & & & & & & & & & Total & $1.562,34$ & 130,2 \\
\hline
\end{tabular}

source : data processed, 2016

The data presented in table 3 above is the overall activity data during the Hexagon Bolt manufacturing process, which consists of value added and non value added activities, while showing a one-year production cycle time in hours / months. Then it will be grouped based on activities that are value added and non value added as in tables 4 and 5 below. 
Table 4. Time for non-value-added activities

(Non Value Added Activity) for one year (hour / year)

\begin{tabular}{clcc}
\hline No. & \multicolumn{1}{c}{ Non Value Added Activity } & Total & Average \\
\hline 1 & Transfer of raw materials from the warehouse & 317,2 & 26,43 \\
& to the production floor (Material handling) & & \\
2 & Weighing raw materials (Material handling) & 316,42 & 26,37 \\
3 & Inspection by QC & 137,28 & 11,44 \\
& $\quad$ Total & $\mathbf{7 7 0 , 9}$ & $\mathbf{6 4 , 2 4}$ \\
\hline
\end{tabular}

Table 5. Value Added Activity for one year (hour / year)

\begin{tabular}{clcc}
\hline No. & \multicolumn{1}{c}{ Processing Time } & Total & Average \\
\hline 1 & Washing of raw materials & 121,84 & 10,15 \\
2 & Withdrawal of raw materials & 126,10 & 10,51 \\
3 & Formation of hexagon bolts & 141,96 & 11,83 \\
4 & Smoothing the sides of the head and thread & 137,12 & 11,43 \\
& bolts & & \\
5 & Washing hexagon bolts & 129,22 & 10,7 \\
6 & Washing hexagon bolts & 135,2 & 11,27 \\
& Total & $\mathbf{7 9 1 , 4 4}$ & $\mathbf{6 5 , 8 9}$ \\
\hline
\end{tabular}

3.1. MCE calculation and productivity under existing conditions (not yet applying the JIT method)

From the data presented in tables 4 and 5 above, the MCE calculation is then carried out following the formula (1) and (2), and the following values are obtained:

Cycle Time $=1562,34$ (hour/year)

$$
\mathrm{MCE}=\frac{7 \quad, 4}{1,3}=0,51=51 \%
$$

Because the value of MCE $<1$ or MCE <100\% means that the production process of the Hexagon Nut bolt still contains many non-value-added activities. Then the non-value added activities must be reduced or even eliminated, and JIT methods are needed to minimize them.

If the value of productivity is calculated according to formula (3), which is a comparison between output or the amount of production produced, with input or time of production consisting of value added and non value added activity, then obtained:

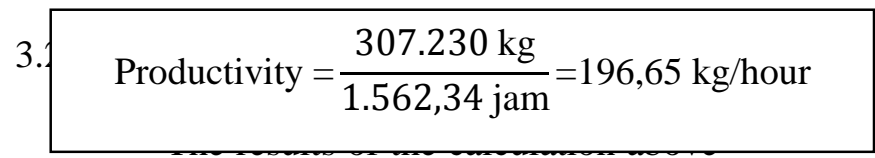

show that non value added activities are still quite high. Continuous improvement needs to be done in an effort to minimize or even eliminate non value added activity from the production of Hexagon Nut bolts, including:

a. Transfer of raw materials from the warehouse to the production floor.

At the location of this research, the raw material warehouse is located far behind the production floor. So that material handling and delivery time are needed relatively long. If using the JIT method, then raw materials are not permitted, especially in a considerable distance from the production floor.

b. Time for weighing raw materials.

The weighing of raw materials may be needed in this manufacturing process because uniformity of shape and weight is needed in each grain of the bolt, but the time taken for weighing needs to be reduced to save production time.

c. Inspection by QC

Inspection is an activity that is not value added, because it requires a long time to check the uniformity of the shape and weight of the product. However, this stage can be eliminated if the raw materials used are very good, and the production process follows the established standards. Or maybe the inspection can be carried out 
immediately when production is in progress. So if there is a product that is not in accordance with the standard, it will automatically exit the production line.

Table 6. Proposed improvement in activities using JIT

\begin{tabular}{|c|c|c|c|c|c|c|c|c|c|c|c|c|c|c|c|}
\hline \multirow{2}{*}{ No } & \multirow{2}{*}{$\begin{array}{l}\text { Production } \\
\text { activity }\end{array}$} & \multicolumn{12}{|c|}{ Processing Time (hour/month) } & \multirow{2}{*}{ Total } & \multirow{2}{*}{$\begin{array}{l}\text { Ave- } \\
\text { rage }\end{array}$} \\
\hline & & Jan & Peb & Mar & Apr & Mei & Jun & Jul & Aug & Sep & Ok & Nov & Dcs & & \\
\hline 1 & $\begin{array}{l}\text { Washing of } \\
\text { raw materials }\end{array}$ & 9,1 & 9,1 & 13 & 10,4 & 9,1 & 13 & 9,1 & 7,8 & 9,1 & 9,26 & 12,48 & 10,4 & 121,84 & 10,15 \\
\hline 2 & $\begin{array}{l}\text { Withdrawal of } \\
\text { raw materials }\end{array}$ & 10,4 & 7,8 & 13 & 10,4 & 13 & 7,8 & 13 & 10,4 & 10,4 & 13 & 7,8 & 9,1 & 126,1 & 10,51 \\
\hline 3 & $\begin{array}{l}\text { Weighing raw } \\
\text { materials }\end{array}$ & 9,1 & 9,1 & 13 & 10,4 & 9,1 & 13 & 9,1 & 7,8 & 9,1 & 9,26 & 12,48 & 10,4 & 121,84 & 10,15 \\
\hline 4 & $\begin{array}{l}\text { Pembentukan } \\
\text { baut Hexagon }\end{array}$ & 13 & 8,32 & 9,1 & 8,84 & 7,8 & 13 & 13 & 13 & 13 & 14,3 & 14,3 & 14,3 & 141,96 & 11,83 \\
\hline 5 & $\begin{array}{l}\text { Smoothing the } \\
\text { sides of the } \\
\text { head and } \\
\text { thread bolts }\end{array}$ & 9,1 & 13 & 7,8 & 13 & 13,52 & 13 & 10,4 & 13 & 10,4 & 10,4 & 14,4 & 9,1 & 137,12 & 11,43 \\
\hline 6 & $\begin{array}{l}\text { Washing } \\
\text { hexagon bolts }\end{array}$ & 10,4 & 13 & 13 & 13 & 8,32 & 10,4 & 10,4 & 10,4 & 13 & 7,8 & 10,4 & 9,1 & 129,22 & 10,77 \\
\hline 7 & $\begin{array}{l}\text { Packing and } \\
\text { storage }\end{array}$ & 13 & 13 & 13 & 10,4 & 13 & 10,4 & 10,4 & 10,4 & 7,8 & 10,4 & 9,1 & 14,3 & 135,2 & 11,27 \\
\hline \multirow{2}{*}{\multicolumn{2}{|c|}{$\begin{array}{l}\text { Total waktu } \\
\text { pengerjaan }\end{array}$}} & 74,1 & 73,32 & 81,9 & 76,44 & 73,84 & 80,6 & 75,4 & 72,8 & 72,8 & 74,42 & 80,96 & 76,7 & & \\
\hline & & & & & & & & & & & & & Total & 913,28 & 76,11 \\
\hline
\end{tabular}

Table 7. Proposed reduction in the time of non value added activities (hours / year)

\begin{tabular}{cllcc}
\hline No. & Non Value Added Activity & Total & Average \\
\hline 1 & $\begin{array}{l}\text { Weighing raw materials } \\
\text { (Material handling) }\end{array}$ & 121,84 & 10,15 \\
& & Total & $\mathbf{1 2 1 , 8 4}$ & $\mathbf{1 0 , 1 5}$ \\
\hline
\end{tabular}

3.3. MCE calculation and productivity after applying the JIT method

The MCE calculation is carried out following the calculation in the previous subchapter (6.1), and the following calculation is obtained.

Cycle Time $=913,28$ (hour/year)

$$
\mathrm{MCE}=\frac{7 \quad, 4}{9,2}=0,86=86 \%
$$

As explained in the previous description, if the MCE value $<1$ or $100 \%$ indicates that there are still non-value-added activities. To realize an MCE $=1$ or $100 \%$, it must eliminate all non-value-added activities.
But there are times when not all non value added activities can really be eliminated. as follows:

While the value of productivity is

Productivity $=\frac{307.230 \mathrm{~kg}}{913,28 \mathrm{hour}}=336,40 \mathrm{~kg} /$ hour

3.4. Comparison of measurement results before and after treatment

The following will show a summary of the results of the MCE calculation and Productivity in the existing conditions or before applying the method and after applying the JIT system to the Hexagon Nut Bolt production process for one year. 
Table 8. Comparison of MCE and Productivity values before and after applying the JIT system in 2016

\begin{tabular}{cccc}
\hline Type of measurement & Before JIT & After JIT & Difference \\
\hline MCE (\%) & 51 & 86 & 35 \\
Productivity (kg/hour) & 196,65 & 336,40 & 139,75 \\
\hline
\end{tabular}

From the results of the calculation above, it shows an increase in the percentage of the MCE value of $35 \%$. That is, there is a reduction in non value added activity by $35 \%$ in one year. Although the value of MCE $<100 \%$, which means that the activity still contains non value added at $14 \%$, it does not mean the company will lose money. However, not all non-value added activities can be eliminated. Because it could be that the activity is a process stage that really needs to be done.

The value of productivity after applying JIT also increased by $139.75 \mathrm{~kg} /$ hour due to the reduction in non value added activities.

\section{CONCLUSSION}

From the above calculations it can be concluded that the application of JIT by reducing and or eliminating non-value added activities will increase the MCE value and productivity per year. That way, consumers are no longer burdened with costs from activities that are not excessively valued. In addition, the products produced are also of high quality so they are able to compete with competitors, and also because production time is faster than before.

\section{ACKNOWLEDGEMENT}

The writers are teacher and a student in an industrial engineering who is interested in research themes about optimization and productivity. In this research still requires comparison methods to get more optimal results. Henceforth, it might to tried using Objective Matrix (OMAX) to obtain a comparative productivity value.

\section{REFERENCES}

1. Ansori, A., Yusianto, R., Tjahyono, R.,, 2015, Penerapan Manufacturing Cycle Effectiveness (MCE) Sebagai Upaya Perbaikan Efektifitas Produksi pada CV. Niaga Manunggal, Psi Udinus, Udinus Repository eprints URL : http://eprints.dinus.ac.id/id/eprint/17 527.

2. Hong, D., Yeh, Mo., ___ Just in Time Manufacturing, University of Toronto, MGT2405. Accessed in https://www.academia.edu/36764453 /8_JUST-IN-

TIME_MANUFACTURING tanggal 03 Juli 2019.

3. Putri, N., Utary, A.R., Nadir, M., 2016, Analisis Manufacturing Cycle Effectiveness (MCE) Dalam Mengurangi Non Value Added Activities, Jurnal Manajemen Volume 8 (2). ISSN Print : 20856911, ISSN Online : 2528-1518.

4. Purnamasari, I., Adhimursandi, D., Nadir, M., 2018, Optimalisasi Manufacturing Cycle Effectiveness (MCE) Terhadap Pengelolaan Value Added Activities dan Non Value Added Activities Dalam Meningkatkan Efisiensi Produksi, Jurnal Manajemen 10 (1), hal 29-37.

5. Singgih, M. L., 2012, Green Productivity Konsep dan Aplikasi, ITS Press Surabaya, ISBN 978-6029494-58-7.

6. Wardhana, R.S., 2018, Analisis Produktivitas Produk Baut Hexagon Nut Tipe M10X 60MM Dengan Metode Just in Time di PT. Abhijana Jaya Braja Sejahtera, Skripsi Mahasiswa Prodi Teknik Industri, Universitas 45 Surabaya. 